\title{
A Discussion on Sedimentary Environment of the Guanyinqiao Member from the Upper Ordovician in Yangtze Area
}

\author{
Yunpeng Xiao1 $^{*}$, Wenjun Liang2, Chunyan Sun${ }^{1}$, Mingyi Hu${ }^{1}$ \\ ${ }^{1}$ Geosciences School of Yangtze University, Wuhan, China \\ ${ }^{2}$ Exploration and Development Research Institute of Huabei Oil Field Company, Petro-China, Renqiu City, China \\ Email: ^201771262@yangtzeu.edu.cn
}

How to cite this paper: Xiao, Y.P., Liang, W.J., Sun, C.Y. and Hu, M.Y. (2018) A Discussion on Sedimentary Environment of the Guanyinqiao Member from the Upper Ordovician in Yangtze Area. Open Journal of Yangtze Gas and Oil, 3, 179-190. https://doi.org/10.4236/ojogas.2018.33016

Received: September 22, 2017

Accepted: July 14, 2018

Published: July 17, 2018

Copyright $\odot 2018$ by authors and Scientific Research Publishing Inc. This work is licensed under the Creative Commons Attribution International License (CC BY 4.0).

http://creativecommons.org/licenses/by/4.0/

\begin{abstract}
Based on the comparison between the sedimentary rate of the Guanyinqiao Member and modern deep sea, as well as the analysis of paleoecology, biopalaeogeographic features, sea level changes and comprehensive sedimentary characteristics, it is demonstrated by the authors that the Guanyinqiao Member in the Yangtze area is formed in the deep sea environment and belongs to contourite facies. The relationship between the events and the mass extinction at the turn of Ordovician-Silurian is discussed. The authors believe that the high-frequency volcanic events, which are widely developed at that time, may be the main and direct cause of the extinction. The coupling effects of volcanic events, iridium and carbon isotope abnormities and the initial hypoxia events in the early Silurian may be the main cause of the extinction of the Hirnantia-Dalmanitina fauna.
\end{abstract}

\section{Keywords}

The Guanyinqiao Member, Sedimentary Environment, Deep-Sea, Mass Extinction, Yangtze Area

\section{Introduction}

Since the foundation of the term of Wufeng Shale Member by Sun Yunzhu in 1931, Chinese geologists have debated the sedimentary environment in this area for over 40 years. Up till now, the controversy is continuing. Generally speaking, there are two main opinions about this issue. Some geologists think that Wufeng Shale Member was formed in the epicontinental sea of continental shelf [1]-[10], and others are in favor of the view of the deep-sea environment [11] [12] [13]. 
The Guanyinqiao Member, which was named by Zhang Mingshao and Sheng Xinfu [11], has been considered as the Shell facies sediment from the shallow sea by most scholars [1]-[10]. It was just because of the Shell facies sediment phenomenon that many scholars simply formed the thinking pattern-the associated environment of the Guanyinqiao Member is shallow sea. Therefore, the further multidisciplinary researches on this issue are often ignored. So far this problem has not yet solved after 70 years' endless argument.

Through the analysis of the sedimentation rate, paleoecology, paleobiogeography, sea-level changes and comprehensive geological characteristics of the Guanyinqiao Member, the authors hold that the Guanyinqiao Member was formed in a deep-sea environment and its associated sediments belonged to the typical deep-sea contourite facies. This view is absolutely contrary to popular opinions. This article aims at drawing the geologists' attention to the Guanyinqiao Member and carrying out the further multidisciplinary research on the mass extinction that occurred at the boundary of the Ordovician and the Silurian. It is believed that it has a great significance to establish the international Geological Stratotype Section and Point (GSSP) of Ordovician to Silurian in our country.

\section{Background and Research Methods}

The Yangtze region starts from the west of Kangdian ancient land. The southeast is limited by the ancient land of Jiangnan. Its scope includes Yunnan, Sichuan, northern Guizhou and northern Hunan, most of Hubei, northwestern Jiangxi, Jiangsu and Anhui, northwestern Zhejiang and other places. In the early Ordovician, Yangtze region was a stable platform, except for the western Kangdian ancient land, southeastern Jiangnan ancient land and northern Huaiyang ancient land. Marine deposition is well developed everywhere. Since the beginning of the middle Ordovician, the sea level in the Yangtze area has been rising, the nodular limestone of shelf and the cracked limestones of deep shelf formed. In the late stage of Ordovician, deep water shale deposits formed due to the maximum rise of the sea level.

All in all, the Ordovician strata in the Yangtze area is well developed. Their stratigraphic sequence has been well known for the geologists at home and abroad represented by Yichang area. The lower Ordovician is composed of Nanjinguan Formation, Fenxiang Formation and Honghuayuan Formation. The middle Ordovician includes Dawan Formation and Guniutang Formation. The Upper Ordovician consists of Miaopo Formation, Baota Formation, Linxiang Formation and Wufeng Formation. The Ordovician includes carbonate sediments, associated with reefs microbial carbonate [14], calcareous shales, with a total thickness of about $329 \mathrm{~m}$. Among them, Wufeng Formation includes two Members, namely, Wufeng shale Member and Guanyinqiao Member. The former is mainly shale sediments, the latter is mainly composed of bioclastic limestone sediments, followed by sandstone and mudstone.

In the course of this study, the author has carried out the methods of field in- 
vestigation, sea level rise rate comparison, morphological function analysis ancient ecological, stratigraphic unit comparison, tectonic analysis and paleontological geography research. It's believed that the Guanyinqiao Member formed during the high sea level, which belongs to the deep sea sediments and the deep sea contourites.

\section{Discussion}

\subsection{Comparison between the Sedimentary Rate of the Guanyinqiao Member and the Current Deep Sea}

Many geologists have been engaged in the research on the sedimentary rate of the current deep sea. Among them, Schopf (1980)stated that the average sedimentary rate of the current deep ocean zone is less than $10 \mathrm{~m} / \mathrm{Ma}$ [15], but the depositional velocity of the contemporary nearshore shallow sea zone is several hundreds meters/Ma. The Japanese scholar ナイスイイシン(1983), who has researched the depositional velocity on modern Pacific ocean, indicating that the velocity of the deep sea area is $1-2.5 \mathrm{~mm} / \mathrm{Ka}$.

Geng Liangyu's study shows that the average sedimentary rate of the Guanyinqiao Member and the Wufeng Shale Member is respectively $0.28 \mathrm{~m} / \mathrm{Ma}$ and $0.27 \mathrm{~m} / \mathrm{Ma}$ [16]. The exact figures are more than that if he takes the compaction of the sedimentary rocks into consideration.

According to many researches, the following formulas can be known:

$$
\begin{gathered}
V=h / M a \\
H=H(1-k)
\end{gathered}
$$

(Notes: $V$-Velocity, $h$-thickness of strata, $H$-primitive sedimentary thickness, $k$-quantity of compaction.)

The research suggests that the $k$ of Ordovician mud shale in the Yangtze area is $62.5 \%$ [17], it is easy to establish the average velocity of the Guanyinqiao Member and the Wufeng Shale Member which respectively are $0.79 \mathrm{~m} / \mathrm{Ma}$ and $0.78 / \mathrm{Ma}$. So if the thickness of Guanyinqiao Member is $h_{\min }=0.1 \mathrm{~m}$ and $h_{\max }=$ $2.1 \mathrm{~m}$, the average velocity is correspondingly calculated as $V_{\min }=0.3 \mathrm{~m} / \mathrm{Ma}$ and $V_{\max }=3.26 \mathrm{~m} / \mathrm{Ma}$. It's unconvincing that the Guanyinqiao Member and Wufeng Shale Member with such little sedimentary rate could form in the normal shallow sea environment. Therefore, by comparing the sedimentary velocity of the Guanyinqiao Member and modern sea, it is suggested that the environment of the Guanyinqiao Member is similar to that of the Wufeng Shale Member and belongs to the typical deep-sea deposits.

\subsection{Palaeoecological Study of the Guanyinqiao Member}

The Guanyinqiao Member contains abundant fossils and Hirnantia-Dalmanitina fauna. The fauna has the characteristics of shell facies. For this reason, many scholars maintain that the sedimentary environment of the Guanyinqiao Member is shallow sea.

Many scholars have done research on the characteristics of Hirnantia-Dalmanitina 
fauna, but they have different opinions about representative environment. For example, Rong Jiayu has made a specific discussion from the fauna's preserved state [3] [4], and his results shows that the water depth represented by this fauna is equivalent to the Boucot (1976) Benthic Assemblages B or C. But Cocks suggested it should match B, and Sheehan proposed it was likely to D or probably E. As an extinction fauna, it is hard to tell which opinion is correct and which is incorrect. Different research angles may bring about different conclusions. With regard to the life style, there is a great discrepancy between Boucot Assemblages $\mathrm{B}$ or $\mathrm{C}$ and Boucot Assemblages $\mathrm{E}$, and the latter is similar to the deep-sea fauna. Therefore, the paleoecologic problem of the Hirnantia-Dalmanitina fauna has not been resolved. By using the morphological-functional analysis and researching on the preservationary state, a different view was put forward in this paper-this fauna belongs to the deep-sea ecological type.

\subsubsection{Morphologic-Functional Analysis of the Hirnantia-Dalmanitina Fauna}

As we know, the orthoid Hirnantia and Strophomenoid Aphanomena of Hirnantia-Dalmanitina fauna don't have any delthyrium or columnal foramen. They own thinner shell, thickset brachiophore and strong muscle scar, their figure is small and near to flat, and their median sinus, fold and prionodont-form margin are all underdeveloped. Among these characters, the thickset brachiophore and developed muscle scar indicate that this kind of organism has a function of opening the two valves freely. The absence of delthydial foramen or columnar foramen suggests that they are not sessile benthos, and the rest features reflect that they might lead a benthic moving mode of life. In a world, it is concluded that they probably lead a pelagic nektonic mode of life.

Dalmanella, Kinella and Draborthis are all characterized by small and light figures, ranging from 5 to $7 \mathrm{~mm}$. Their shell is thinner and has delthydial foramen or columnar foramen. In addition, their median sinus, fold and prionodont-form margin are all underdeveloped as well. The thinner shell, small figure and undeveloped median sinus, fold and prionodont-form margin indicate that these organisms are not sessile benthos. It's possible that they lead a pseudoplanktonic (attached planktonic) mode of life, judging by the developed delthydial foramen or columnar foramen, thinner shell, small and light figure.

The features of Strophomenoid Aegiromena, Leptaena and Leptaenopoma are as follows: small and light, with thinner shell, very little or even underdeveloped deltoid formen and well-developed musclescar. These characters show that they probably lead a pseudoplanktonic mode of life in the early stage, but shift into a nektonic mode in the late stage.

Rynchonelloid Plectothyrella doesn't possess any elthydial foramen or columnar foramen, and is characterized by small figure, thick shell, remarkable median sinus and fold, prionodont-form margin, and extremely thickset radial plicae. Among these characters, the thick shell demonstrates that these organisms can endure the high pressure from the deep-water. The remarkable median sinus and fold, thickset radial plicae, well-developed prionodont-form margin 
and the absence of the columnar foramen indicate that these organisms lead benthic moving or freely recumbent mode of life. Trilobitoid Dalmanitina owns prominent features: small eyes, one pygidial spine and with nodules or small projection on its carapace surface. The nodules or small projection on its carapace surface imply that they possibly lead benthic moving mode of life in the deep-sea, and that specially one pygidial spine is an indicative of benthic moving mode.

\subsubsection{Analysis on the Preservational Features of Hirnantia-Dalmanitina Fauna}

Many scholars maintain that the sedimentary environment of the Guanyinqiao Member is the shallow sea because it not only contains abundant animal fossils, but also has the assemblage preservation and many visible shell fragments. As a matter of fact, the assemblage preservation is not unique for shallow water organisms. Except for them, the planktonic, pseudoplanktonic, nektonic organisms and even a part of their body also have such features, such as Cambrian Agnostids, Discosphaera, Devonian Tentaculitid, Mesozoic Belemnoidea and Graptolite and Kornite which appear in some strata of Ordovician to Siluran.

As for the reason why many shell fragments are visible in the Guanyinqiao Member in some parts of the research region, the authors explain it is the result of the ocean current transportation. A lot of studies have indicated that the currents at the bottom of the ocean are very active [18]-[22], they can transport the grains in various size to different depths and gradually deposit along the isobath or at the bottom of the ocean (Please refer to the following demonstrations). In fact, the bioclastic contourite is a main type among the ancient contourites [20] [21] [22].

\subsection{Palaeobiogeographical Characteristics of the Guanyinqiao Member}

Lots of studies have proven that the characteristics of Palaeobiogeographical distribution have been strictly controlled by the factors such as: ecological condition [23], ecological type, distribution ability, geographical barrier, temperature-latitude, plate structure and so on. Limited by life mode, distribution ability, geographical barrier and other factors, the neritic benthonic organisms have limited regional developing characteristics in the geographical distribution. In many cases, their endemic species are well-developed. Being opposite to neritic benthonic organisms, the planktonic, pseudoplanktonic, nektonic organism and deep-water benthonic organisms have wide distribution ability, thus, their endemic species are very few.

The Hirnantia-Dalmanitina fauna is famous for the characteristics of intercontinental distribution during the late age of late Ordovician, which was widespread in the Yangtze Area and northern Xizang of China, western Europe, northern Africa, southern part of south America and other areas [3]. The neritic benthic organisms don't own such characters mentioned above, so the theory of neritic fauna of shelly facies can not elaborate the phenomenon. So from the view of paleobiogeographic characteristics, the Guanyinqiao Member should 
belong to the deep-water ecological type.

\subsection{Changes of Sea Level during Wufeng Age}

The change of sea level during the late Ordovician has been discussed by many scholars and most of them suggested the sea level at that time should be in a state of continuous descending [1]-[10]. Such a suggestion was made upon the evidence of sea-level descending due to the northward subduction of the ocean crust plate in southern China and the glaciation event of southern continent during that time. After analyzing the stratigraphy of Ordovician in Yichang area, we found the sea level of the early Wufeng age was right at its upmost height then [13]. This conclusion is coincident with Feng Hongzhen's view based on the palaeosalinity analysis. The typical deep-water condensed section represented by the Wufeng Graptoid shale in Yangtze area formed just because of the largest elevation of the sea level. As we know, the ocean current often appears at the high sea-level, so a great number of contourites came into being, and from the above analysis, the sediments of the Guanyinqiao Member just belong to the contourite. What's more, the reason for the sea-level elevation during the early Wufeng age in Yangtze can be effected by the following factors.

\subsubsection{Geotectonical Cause}

Due to the drift of the cathaysia plate to the West and the Northwest, the northern part of the southern China ocean (Palaeosouthchina Ocean) closed gradually in late Ordovician [10] [24] [25]. This action made the southeastern margin of the Yangtze Plate extruded intensely, causing the inner part of the Yangtze Plate subside quickly. Meanwhile, the sea level rapidly rose, leading to the result that the deep-sea basin gradually migrated from the eastern lateral part of Jiangnan area to northwestwards during the early Ordovician and evolved into the deep-water basin of the Yangtze Plate at the late period of late Ordovician. This viewpoint can be proved by the following arguments: 1) Before the middle Ordovician Baota Age, the sediments were always transported from the northwest (Yangtze area) to the southeast (Jiangnan area). At that time, there were typical pelagic fine-grained sediments in the deep-water basin located in southeastern side of the Jiangnan area since the late age of late sinian Epoch [24]. 2) After the middle Ordovician Baota Age, the transportation direction was just opposite-from southeast to northwest. At the same time, the deep-water basin in the southeastern side of Jiangnan area developed into a continental slope with giant-thicked phenoclastic sediments, meanwhile the pelagic fine-grained sediments were developed in the Yangtze area, demonstrating the deep-water basin migrated to the northwestwards [10] [24]. 3) Researches have shown that abundant pyroclastic rocks and bentonites were developed in the Wufeng Formation [12] [26]. The number of pyroclastic rocks amounts to 97 beds; while the layer of bentonites is 19 bed, which is caused by volcano eruption. Also, it has been proved that the pyroclastic rocks and bentonites belong to intermediateor alkali-intermediate [12] [26], and the frequency of volcanic eruption is $8-18$ 
times/Ma. According to Radiolaria existed and massively developed intermediate or alkali-intermediate pyroclastic in Wufeng Formation, Huang Zhi-cheng thought that the Wufeng Formation belongs to deep-sea sediments [26], and the pyroclastic rocks related to continental crust-source magmatism are caused by the violent extension of the continental margin. His viewpoint is supported by the authors of this paper.

\subsubsection{Ablation of Glacier in the Interglacial Age}

When studied on the Ordovician contourite in Lackland area of east Australia, B.G.Jones has proved that during the Wufeng Age, the south continent was in an interglacial age, and the ablation of glacier led to the elevation of the sea level [26]. His viewpoint happened to be coincident with the result of Feng Hongzhen's palaeosalinity analysis [9]. Even during the glaciation period of Caradoc Age and the Arenig Age, it has no influence on the sea level in the south China, meantime, the sea level was still rising [13].

\subsubsection{A Large Number of Fresh Water Injection}

During the Ordovician Period, the Yangtze area was characterized by a great number of organic reefs [27] [28] [29], which indicates that the Yangtze area was located near the equator. Because the rainfall is sufficient near the equator, lots of injected fresh water made the Yangtze small ocean basin turned into a limnetic sea [7] [9], and caused the rise of the sea level. The palaeosalinity analysis has shown that there are twice sea-level risings in the Yangtze area during the Wufeng Age, which occurred respectively during the early time of the Dicellograptus szechuanensis Zone and the time of D.bohemicus-Glyptograptus persculptus Zone [9].

\subsection{Comprehensive Characteristics and Event Deposit}

Guanyinqiao Formation of Yangze area has the following common geological features which differ from that of the shallow sea: 1) Widespread. Its distribution range has even exceeded the scope of the remarkable boundary clay bed since Phanerozoic eon. 2) Extremely thin thickness. With the average of 10 to $30 \mathrm{~cm}$ (Figure 1), $1.1 \mathrm{~m}$ is the utmost figure. 3) Low sedimetary velocity. It's merely $0.79 \mathrm{~m} / \mathrm{Ma}$ in average. 4) It contains the intercontinental distributional fauna-Hirnantia-Dalmanitina fauna, which belongs to the deep-water ecological type. 5) The appearings of manganese nodule and the manganese-bearing sediments [10] [11], which are testified to only exist at the bottom of the ocean with very low sedimentary rate [18] [19] [30] [31], and the manganic nodules, are usually found in the deep channel by eroding current. 6) We can define the color of the Guanyinqiao Member sediments as variegated, ranging from black, gray, gray-green, gray-yellow to brown, dark-brown, etc. Through a specific study about the discovered deep-sea sediments, particularly contourite, the authors argue that the colour presented by the Guanyinqiao Member sediments is very similar to that of bathyal or abyssa contourite [18] [24] [25]. 7) The Guanyinqiao Member is composed of clastic rocks, mudstones, argillaceous limestones, bioclastic 
limestones, pyroclastic rocks, bentonites and so on. Among them, the clastic rocks are often featured by inverse grading, most pelitic sediments contain sand or silt, the banded structures are well-developed in mudstone and argillaceous limestone, the erosion surfaces are frequently visible on the top or at the bottom of the clastic and bioclastic rocks. Besides, the lamination, biogenic burrow and bioturbated structures are all well-developed in this region [7], and the limestone and marl are interbedded between the mudstone and the shale in the form of lenticular [10]. The above-mentioned characters are typical in the contourite [18] [24] [25]. The lithology, thickness, structure combined with the underlying siliceous shale with radiolarians and graptoids and overlying graptolite-bearing shale, suggesting the environment of this area is not suitable for shoreface facies to the continental shelf facies. No matter at home or abroad, it is hardly to see a suite of the extremely thin neritic sediments interbedded between a suit of thin siliceous shale with radiolarians and graptoids and a suit of graptolite-bearing shale. 8) The lithofacies of different types (sandy lithofacies, argillaceous lithofacies and bioclastic lithofacies) are provided with a sheet or giant-banded distributional characters (Figure 2). Among them, the sandy lithofacies are roughly distributed along a line of Lebo (South Sichuan)-Qijiang (South Sichuan)-Xiushan (Southeast Sichuan)-Yichang(West Hubei) and its north; The argillaceous lithofacies is mainly distributed along the line of Lebo (south Sichuan)-Qijiang (South Sichuan)-Xiushan (SoutheastSichuan)-Yichang (west Hubei). The line of Bijie (North Guizhou)-Zunyi (North Guizhou)-Tongren (Northeast Guizhou) and in the lower Yangtze area; The bioclastic lithofacies is mainly distributed in the area to the south of Bijie (north Guizhou)-Zunyi-Tongren of northeastern Guizhou and the area from Hanyuan(west Sichuan) to Weiyuan (central Sichuan). Studies have pointed out that the sheet and giant-banded shape of contourite are considered as the main sediments in the modern ocean [18], and the former is considered as the product of fairly restricted deep sea basin because deep water circulation is intercepted in it [32]. 9) In some parts of the Yangtze area, the phenomenon of totally or partially lost of Wufeng Formation's strata can be seen. As we know, a lot of researches have demonstrated that the current energy is very active in the ocean bottom and the continental margin. In the place where the current energy is strong, sediments are often eroded and taken away [18] [19] [30] [31]. From that it is easy for us to understand why the underwater erosional unconformity is well-developed in the contourite. Therefore, in our opinion, the phenomenon lost layer is caused by the erosion effect of the ocean current rather than the onland denudation. According to the analysis mentioned above, it is concluded that the Guanyinqiao Member belongs to abyssal deposition and it's the result of the contoured flow. Yangtze area was a small ocean basin during Wufeng and early Longmaxi Age, but turned into a continental slop in the middle Longmaxi Age. Many researchers have shown that Ordovician stage was one of the periods with the greatest transgression in the history, and a period in which the event of the glaciation and glacier-melting took place alternately as well [18]. And during the sea level rise and high sea lev- 
el period, glaciers-ice-melting events in the transition period, ocean current events often occur [18] [24]. Therefore, the sediments of the ocean current have been discovered through all over the Ordovician Member [18] [24] [25]. The ocean current of the Guanyinqiao Member is a witness of the late Ordovician.

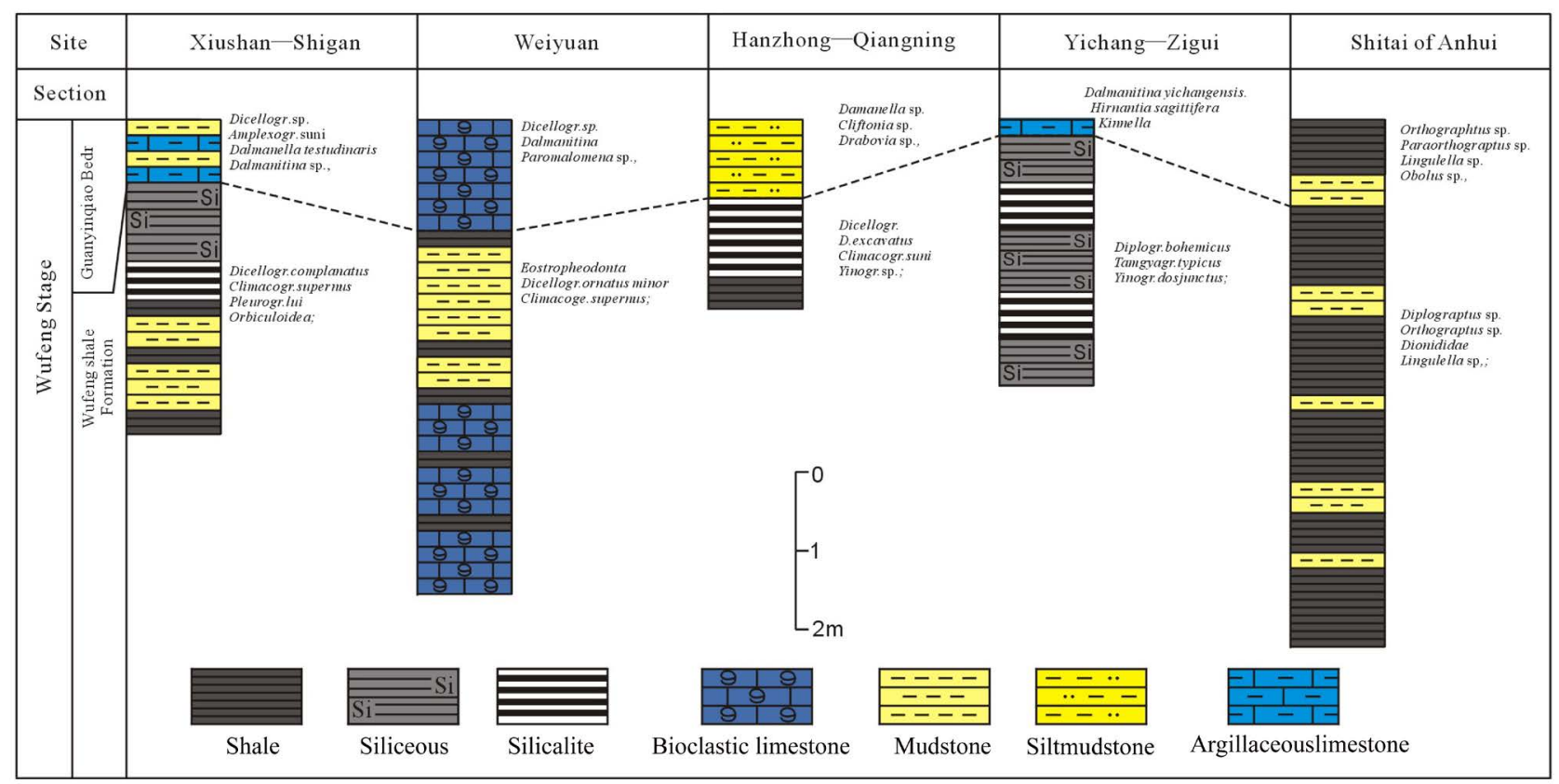

1-Shale; 2-Siliceous; 3-Silicalite; 4-Bioclastic limestone; 5-Mudstone; 6-Siltmudstone; 7-Argillaceouslimestone.

Figure 1. Stratigraphic Correlation of Guanyinqiao Age in Late Ordovician of Yangtze Area.

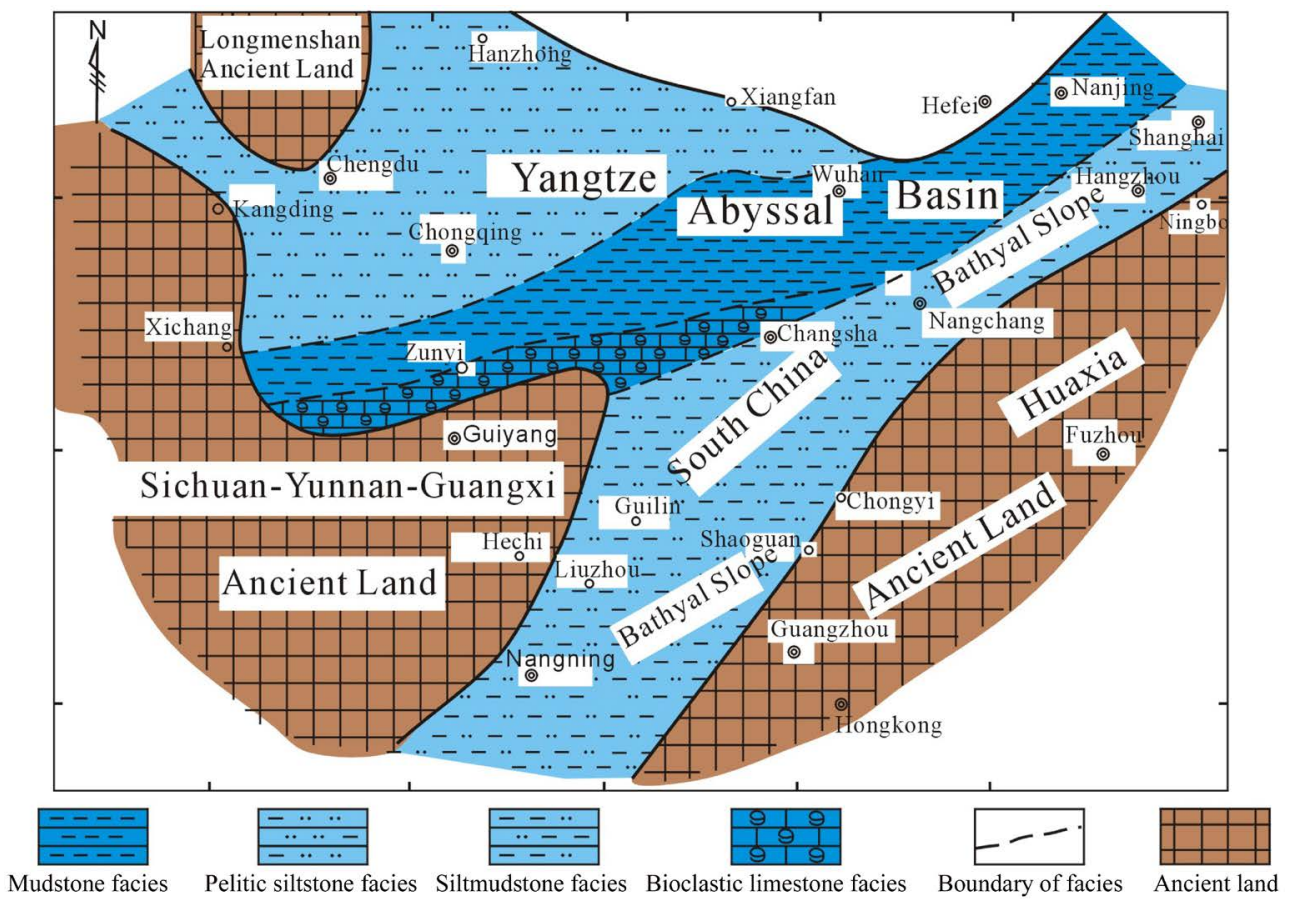

1-Mudstone facies; 2-Pelitic siltstone facies; 3-Siltmudstone facies; 4-Bioclastic limestone facies; 5-Boundary of facies; 6-Ancient land.

Figure 2. Palaeogeographical Map of Lithofacies During Guanyinqiao Age in Late Ordovician of Yangtze Area. 


\section{Preliminary Exploration on the Relationship between the Group of the Geological Events and the Organic Mass Extinction at the Ordovician-Silurian Boundary}

Nowadays, through the study of geological characters, many significant events occurring at the Ordovician-Silurian boundary are recognized, such as the volcanic event [7] [26], the anoxic event, the alternative event of the glaciation and the glacier-melting [27], the anomal event of the iridium and carbon isotopes, the event of organic mass extinction [5] [6], the event of oceanic current and so on. Among them, the volcanic event and the event of organic extinction are the most prominent. The volcanic event was not only widespread, but also erupted in high-frequency [7] [26], for example, in the lower Yangtze area, 97 beds of the pyroclastic rocks were developed only in the strata with the thickness of $6.33 \mathrm{~m}$; In the upper Yangtze area, 26 beds of the volcanogenic bentonites were developed at the bottom of the Wufeng Formation and Longmaxi Formation. It is expected that there will be more amazing discoveries after a detailed survey.

According to the statistics, there were tremendous changes of organisms at the Ordovician-Silurian boundary, the types and intensity of organic extinction were only inferior to that of Permian-Triassic boundary. 100 families of the marine invertebrates and half of the primary echinoderms'families died out at the Ordovician-Silurian boundary. The orginal 70 generas of Tabulata and Heliolites sharply reduced to 50 and merely 4 species out of 3 generas survived from the former 88 species out of 19 generas. The most remarkable event is that the well-known Hirnantia-Dalmanitina fauna became entirely extinct.

There are two different opinions on the mass extinction occurred at the boundary of the Ordovician and the Silurian now. Some scholars think it's a result of the combined effects of the sea-level descending and the cold sea water caused by the glaciation [3] [4]; whereas others argue it might be corresponding to the event of the iridium and carbon isotopes abnormity (extraearth event) [6]. However, at that time the Yangtze area was located near the equator and the event of the glaciation mainly occurred in the southern continents. Therefore, the glaciation did not bring great effects to our country, and it was impossible to make the intercontinental organic extinction, particularly the extinction of the Hirnantia-Dalmanitina fauna. Besides, the iridium and carbon isotopes abnormity might be related to the event of volcanism, Yin Hongfu has made a detailed discussion about these. The paper holds that the widespread and high-frequency events of volcanism might probably the main and direct reason for the mass extinction event that occurred at the boundary of the Ordovician and the Silurian, and volcanic event.

\section{Conclusions}

According to the analysis mentioned above, it is concluded that the Guanyinqiao Member belongs to the abyssal deposition and it's the result of the contoured flow.

The authors hold that the widespread and high-frequency events of volcanism are probably the main and direct reason for volcanic event and the mass extinction event that occurred at the boundary of the Ordovician and the Silurian. The 
coupling effect of volcanic events, iridium and carbon isotope abnormity and the initial hypoxia events at the intersection of the Ordovician-Silurian may be the main cause of the Hirnantia-Dalmanitina fauna extinction.

\section{Acknowledgements}

This work was completed under favor of Prof. Gao Zhenzhong and Prof. Jiang Yanwen and supported by National Natural Science Fund.

\section{Fund}

The project are supported by National Natural Science Foundation of China (No. 41572322).

\section{References}

[1] Mu, E.Z. (1954) On the Graptolite Shale. Acta Palaeontologica Sinica, 2, 153-170. (In Chinese with English Abstract)

[2] Chen, X. and Qiu, J.Y. (1986) The Paleoenvironment Evolution of Ordovician in Yichang Area. Journal of Stratigraphy, 10, 1-14. (In Chinese with English Abstract)

[3] Rong, J.Y. (1984) The Ecostratigraphic Evidences of Regression during Late Ordovician in Upper Yangtze Region and Glacial Influences. Journal of Stratigraphy, 8, 19-30. (In Chinese with Abstract)

[4] Rong, J.Y. and Chen, X. (1987) Faunal Differentiation, Biofacies and Lithofacies Pattern of Late Ordovician in South China. Acta Palaeontologica Sinica, 26, 508-526. (In Chinese with English Abstract)

[5] Wang, X.F. (1989) Palaeogeographic Reconstruction of Ordovician in China and Characteristics of Its Sedimentary Environment and Biofacies. Acta Palaeontologica Sinica, 28, 234-248. (In Chinese with English abstract)

[6] Wang, X.F. and Chai, Z.F. (1989) Terminal Ordovician Mass Extinction and Its Relationship to Iridium and Carbon Isotope Anomalies. Acta Geologica Sinica, 63, 256-264. (In Chinese)

[7] Cheng, H.J. and Wang, Y.Z. (1991) The Exploration of Yangtze Desalinated Sea during Wufeng Age. Journal of Stratigraphy, 15, 109-114. (In Chinese)

[8] Fang, Y.T., Bian, L.Z. and Yu, J.H. (1993) Sedimentary Environment Pattern of Yangtze Plate in Wu feng Age of Late Ordovician. Acta Sedimentologica Sinica, 11, 7-12. (In Chinese with English Abstract)

[9] Feng, H.Z., Yu, J.H. and Fang, Y.T. (1993) The Analysis on Paleosalinity of Upper Yangtze Sea in Wufeng Age. Journal of Stratigraphy, 17, 179-185. (In Chinese)

[10] Zhou, M.K., Wang, R.Z., Li, Z.M., et al. (1993) Ordovician-Silurian Lithofacies Paleogeography and Mineralizeation of Southern China. Geological Publishing House, Beijing, 7-93. (In Chinese with English Abstract)

[11] Sheng, X. (1974) The Subdivision and Correlation of Ordovician in China. Geological Publishing House, Beijing, 53-68. (In Chinese)

[12] Huang, Z., Huang, Z. and Chen, Z. (1991) Volcanic Rock and Radiolarian Silicilith of Wufeng Formation in Lower Yangtze Region. Acta Sedimentologica Sinica, 9, 1-14. (In Chinese)

[13] Xiao, C., Jiang, Y. and Zhu, Z. (1996) A Study on Ordovician Sequence Stratigraphy in Yichang District, Hubei and Sedimentary Environment of the Wufeng Formation in Yangtze Area. Geological Journal of China Universities, 2, 339-347. (In Chinese) 
[14] Xiao, C., Li, M., Yang, W. and Hu, M. (2011) Palaeoecology of Early Ordovician Reefs in the Yichang Area, Hubei-A Correlation of Organic Reefs Between Early Ordovician and Jurassic. Acta Geologica Sinica, 85, 1004-1015.

[15] Schopf, T.J.M. (1980) Palaeoceanography. Harvard University Press, Cambridge, 45-136.

[16] Geng, L. (1986) On the Epicontinental Origin of the Wufeng Shale in the Yangzi Area. In: Selected Papers of the 13th and 14th Academic Annual Meetings of the Chinese Paleontological Society, Anhui Science and Technology Press, Hefei, 103-114.

[17] Li, J., Liu, B., Zhu, Z. and Hu, M. (1993) Compaction of Carbonate Rocks in Lower Ordovician Dawan Formation in Songzi, Hubei. Oil and Gas Geology, 14, 278-284. (In Chinese)

[18] Wang, Q. and Zhu, E. (1989) Oceanic Geology. Science Press, Beijing, 108-112. (In Chinese)

[19] Jiang, Y., Wu, Z. and Wang, Z. (1993) Advance of Study on Deep-Sea Contourite Sedimentology. Xibei University Press, Xian, 5-167. (In Chinese)

[20] Duan, T., Guo, J. and Gao, Z. (1990) A Lower Ordovician Carbonate Contourite Drift on the Margin of the South China Paleocontinent in Jiuxi, Northern Hunan. Acta Geologica Sinica, 64, 131-143. (In Chinese)

[21] Gao, Z., Luo, S. and He, Y. (1995) The Middle Ordovician Contourite on the West Margin of Ordos. Acta Sedimentologica Sinica, 13, 16-25. (In Chinese)

[22] Gao, Z., et al. (1996) Deep-Water Tractive Current Deposits. Science Press, Beijing, 108-112. (In Chinese)

[23] Yin, H., et al. (1988) Paleobiogeography of China. Press of China University of Geosciences, Wuhan, 138-184. (In Chinese)

[24] Duan, T., Zeng, Y. and Gao, Z. (1988) The Analysis on the Evolution of the South China Paleocontinental Margin Based on the History of Sedimentology. Oil and Gas Geology, 9, 410-420. (In Chinese)

[25] Yin, H., Wu, S., Du, Y. and Peng, Y. (1999) South China Defined as Part of Tethyan Archipelagic Ocean System. Journal of China University of Geosciences, 24, 1-12. (In Chinese)

[26] Su, W., He, L., Wang, Y. and Gong, S. (2002) Bentonite and High-Resolution Integrative Stratigraphy of Wufeng Formation and Basal Longmaxi Formation in Ordovician to Silurian in South China. Science in China $(D), 32,207-220$. (In Chinese)

[27] Jones, B.G., Fergusson, C.L. and Zambelli, P.F. (1993) Ordovician Contourite of Lakelan Folder in East Australia. In: Advance of Study on Deep-Sea Contourite Sedimentology, Xibei University Press, Xian, 5-167. (In Chinese)

[28] Zhu, Z. (1993) Study on Organic Reefs in the Lower Ordovician in Huanghuachang of the Eastern Yangtze Gorge. Scientia Geologica Sinica, 28, 1-9. (In Chinese)

[29] Xiao, C., Jiang, Y. and Liu, B. (1993) A Discovery of Batostoma Genus of Early-Middle Age of Early Ordovician and a Study on Its Geologic Function and Ecology in Middle Yangtze Area. Chinese Science Bulletin, 38, 1314-1316. (In Chinese)

[30] Shen, X. and Guo, B. (1993) Oceanic Geology. Press of China University of Geosciences, Wuhan, 138-184. (In Chinese)

[31] Xu, D., et al. (1994) Ancient Marine Environment for Multimetallic Nodule. Geological Publishing House, Beijing, 6-92. (In Chinese)

[32] Egloff, J. and Johnson, G.L. (1975) Morphology and Structure of the Southern Labrador Sea. Canadian Journal of Earth Sciences, 12, 2111-2133.

https://doi.org/10.1139/e75-186 